\title{
C A E
}

\section{1.はじめに}

エンジニアリングプラスチックスが，その優れた性能の ために構造材料や精密部品等にも大量に消費されるように なり，それらの成形技術も著しく向上している.プラスチッ ク成形加工業界において，CAE は合理性（製品の品質向 上，製造コストの低減，製品開発リードタイムの短縮等) 追求の手段として活用されている。そのなかでも特に射出 成形品の反り量を事前に知ることは，開発期間の短縮や品 質の高い成形品をつくる上で最も重要であり，予測技術の 精度向上は，設計者や成形技術者から強く要求されている ここでは射出成形 $\mathrm{CAE}$ ，特に反り解析について紹介する。

\section{2 次元解析}

溶融樹脂流動は熱の移動を伴う非圧縮性流体の非定常挙 動であり, 連続の式, 運動方程式, エネルギー式を, メル トフロントの進展を考慮しながら解き続ける．従来，樹脂 流動解析は Hele-Shaw 流れを基礎にした解析が一般的で あった.これは樹脂流れを 2 次元化して支配方程式を単純 化し，圧力のラプラス式を解く手法である.

この 2 次元化によって，当時の計算機でも短時間でメル トフロントの進展を予測できるようになった。 また，計算



1）段差



2) 厚肉

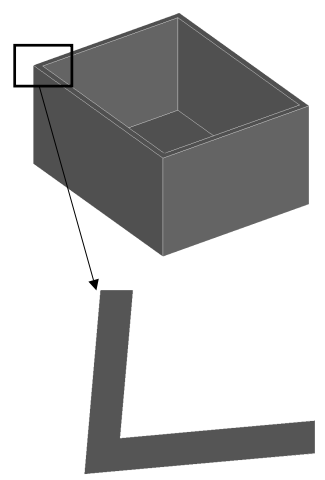

3）反り解析時 コーナー部分の倒れ
図 12 次元化で発生する問題

\footnotetext{
* Shimomai, Ken

三菱エンジニアリングプラスチックス侏 技術センター製品技術室 平塚市東八幡 5-6-2（テ254-0016） 2004.5.10 受理
}

モデルにはシェル要素を用いるので肉厚変更や設計変更に も簡単に対応できた。しかしながら，2次元化したため次 のような問題も生じていた（図 1).

1 ）段差形状などは正確にモデル化できない.

2 ）厚肉成形品の 3 次元樹脂流れを表現できない.

3 ）反り解析で，コーナー部倒れ込みを表現できない.

\section{3 . 3 次元解析}

3 次元計算は膨大な計算量が必要になるが，最近の計算 機の急速な進歩によって実用的な時間で処理が可能となっ てきた。これに加え CAD の 3 次元化，低価格化も進み， 製品設計を 3 次元 $\mathrm{CAD}$ で行うケースも多くなってきた. 設計用 3 次元モデルと従来必要だった計算用 2 次元モデル を別個に作成しなくて良い点からも 3 次元解析に対する期 待は高い.

計算モデルとしてへキサ要素を利用する場合，メッシュ 生成手法としてはボクセル分割が有力である。これは 3 次 元直交格子により形状をギザギザに近似する手法で，境界 が階段状になる問題があったが，最近は節点を CAD デー 夕表面に移動させ，形状近似精度を向上させるメッシュ作 成技術が開発されている ${ }^{1)}$.テトラ要素の場合は，アドバ ンシングフロント法が有力である。これは領域の境界から 内部に向けて要素を生成させる手法で，ほとんど手間をか けずにテトラ要素が得られる。アドバンシングフロント法 では，メッシュ生成を 2 段階に分けられるのも利点である.

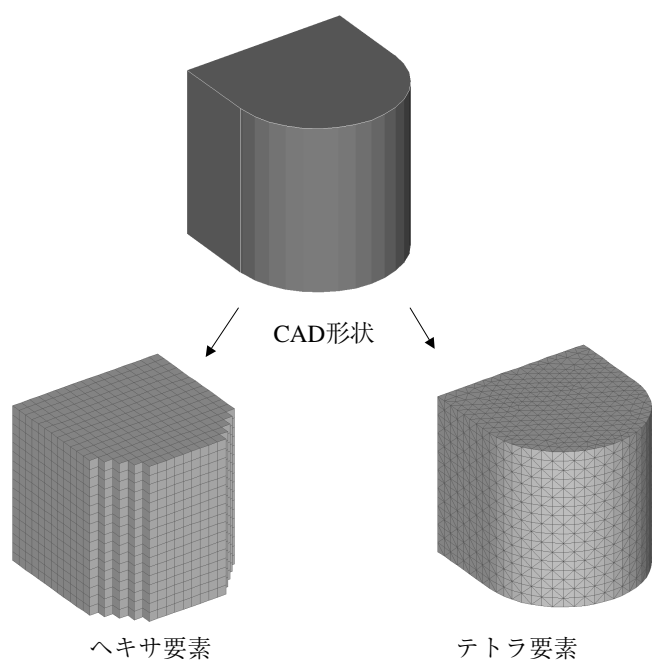

図 2 ソリッドメッシュ 


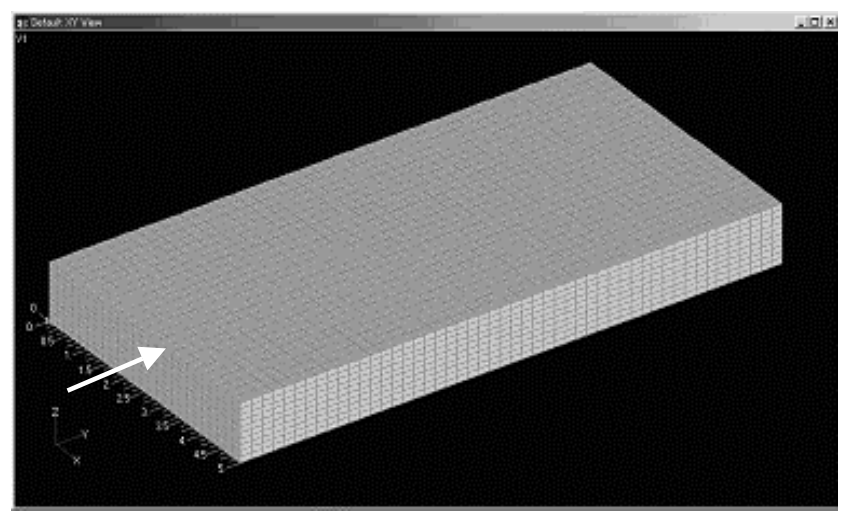

図 3 計算モデル

大きさ： $10 \mathrm{~cm} \times 5 \mathrm{~cm} \times 1 \mathrm{~cm}$. 樹脂注入位置を矢印 で示す．射出速度： $40 \mathrm{cc} / \mathrm{s}$

まず形状表面に表面メッシュを生成し，続いて内部に向け てテトラ要素を発生させる．表面メッシュさえ発生できれ ば，極めて複雑な形状でもテトラ要素を作成できる（図 2).

実際の計算では，モデルに1層の部分が存在すると問題 が生じる.1 層部分の節点は，そのすべてが金型壁面と接 するため, 圧力勾配が存在しても流速は常にゼロであり, 温度も金型温度と等しくなってしまう。この問題に対し, メッシュを細分化することなく自動的にシェル要素として 取り扱う技術も開発されている ${ }^{12}$. 温度計算においても, 肉厚方向に温度計算点を多数配置して伝熱計算精度を向上 させる工夫もなされている11.

当社でも SIMPLE 法による 3 次元流動解析用ソルバー を開発した経験がある ${ }^{2}$. 平板の流動解析結果を図 3, 図 4 に示す. 3 次元流れが再現され厚み方向に流速が存在して いる. 充填 1.25 秒後の温度分布を見ると, 平板厚さ方向

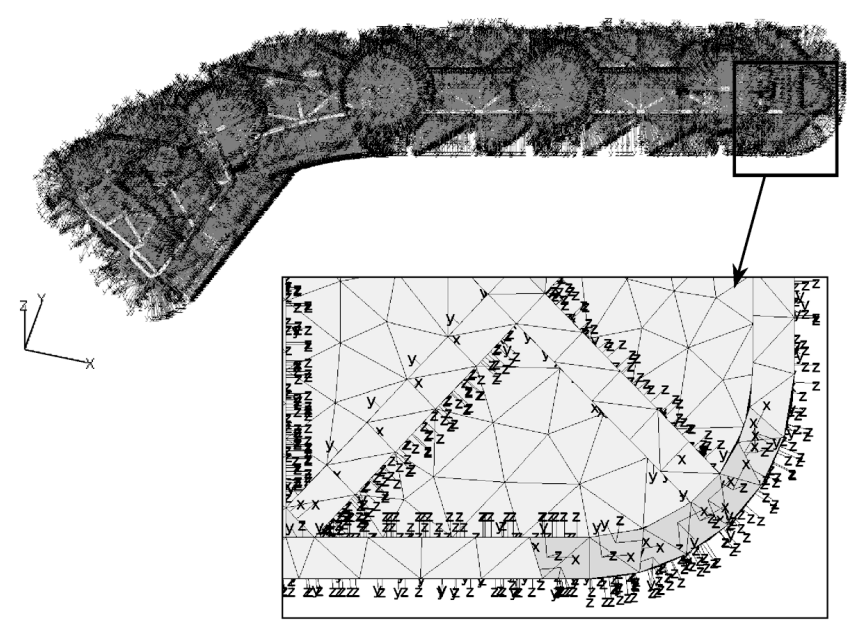

図 5 収縮異方性の表現

に温度分布があり，メルトフロント先端には高温部が存在 している.これらは 2 次元計算では得られない結果である。 最近の計算機は著しく高速化したが，実用的なモデルの 3 次元流動解析が数分で終了する程ではない. 3 次元解析 でも，圧力のラプラス式を解くことで計算速度を向上させ る方法もある ${ }^{3}$. また，計算機をクラスター化し並列計算 によって高速化する研究も行われている.

\section{4. 熱応力解析（収縮解析）}

流動解析の結果, キャビティ内の樹脂流速, 圧力, 温度 が得られる。この結果を利用し熱応力解析を実施して収縮 量（反り，ひけ）を計算する。これは市販の反り解析ソフ トゥェアに共通する手順であるが，流動解析結果を利用す る部分にソフトウェア開発各社の工夫が盛り込まれている
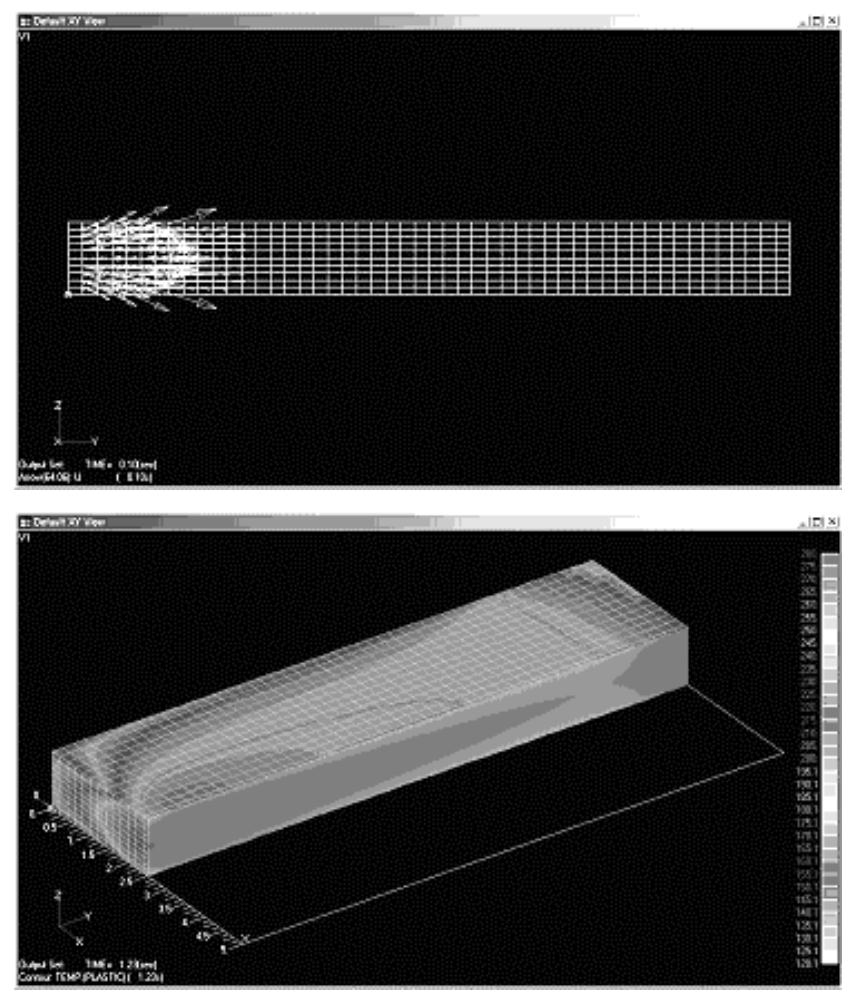

図 4 計算結果
0.1 秒後の流速ベクトル

1.25 秒後の温度分布 



図 6 反り計算結果と実測値の比較

様である．例えば，ASU-MOLD（反り解析ソフトウェア 一(制先端力学シミュレーション研究所発売)では, 収縮異方 性を考虑して反り計算を行っている．流動解析結果から得 られた収縮異方性を図 5 に示す。要素ごとに収縮異方性が 直交異方性により定義されている. 最終的な反り解析結果 と実測値は良い一致をすることが確認されている4)(図 6).

\section{5 、樹脂データベース}

流動解析を行うためには，樹脂粘度，比熱，熱伝導率， 密度など様々な物性データが必要になる。通常, 樹脂粘度 は細管粘度計により測定され，バグレイ補正など様々な補
正の後に，粘度パラメー夕に変換されて利用される．しか しながら，こうして得られたパラメータを使用しても，細 管粘度計の実験結果すら正確に再現できないのが現状であ る. 最近，最適化手法を用いて，実験結果に合う様に樹脂 デー夕を逆算する方法が提案されている5.

熱応力解析でも, PVT デー夕, 線膨張係数, 弾性率な どの物性デー夕が必要になる。実成形では，成形品内部で 流動や冷却の状態が一定ではないため，結晶化や分子配向 度に分布が生じ, 線膨張係数などの物性值も一定值とはな らない.ミクロトーム等により表面に対し平行方向に薄片 を切り出して試験片とし, 結晶化度, 線膨張係数を測定し てそり予測精度を向上させる研究も行われている ${ }^{6}$.

\section{6.おわりに}

3 次元流動解析が急速に進化し，反り予測技術は格段の 進歩を遂げている。これまで不可能であった複雑な成形品 に対しても，かなりの精度で変形を予測可能になりつつあ る.結晶化や繊維配向の問題，伝熱の取り扱いなど残され た課題も多いが，解析精度の検証をしながら，これらの問 題の解明が進むことを期待する.

\section{参 考 文 献}

1 ）中野，坂場，澤田，結城，須賀：成形加工， 15(6)，550 (2003)

2 ）奈良崎：加工プロセスシミュレーションシリーズ 4 流 動解析一プラスチック成形，コロナ出版 (出版準備中)

3 ) 特開平 8-99341

4 ）則包：プラスチックス（掲載準備中）

5 ）青木, 佐藤：成形加工’ 03，333（2003）

6 ）瀬戸，寺倉，佐々木，山部：成形加工，15（2， 148 (2003) 